\title{
Evaluation of Locally Available Energy Source Feeds on Fattening Performance of Local Oxen and Carcass Analysis in Wolaita, Southern Ethiopia
}

\author{
Zekarias Bassa $^{1 *}$, Shewangizawu Wolde ${ }^{1}$, Tesfaye Alemu ${ }^{2}$, Melese Yilma ${ }^{1}$, Asrat Terra ${ }^{1}$, Berekt Zeleke ${ }^{1}$ and Deibe Gemiyu ${ }^{1}$ \\ ${ }^{1}$ Southern Agricultural Research Institute, Areka Agricultural Research Center, Areka, Ethiopia \\ ${ }^{2}$ Ormiya Agricultural Research Institute, Adami Tulu Agricultural Research Center, Areka, Ethiopia
}

\begin{abstract}
A study was conducted to evaluate the effect of supplementing Taro (Bolosso-1), Enset corm and Sugarcane stock on feed intake, weight gain and net return of fattening local oxen. Sixteen local un-castrated oxen of about 5 years' age and average weight of $249 \mathrm{~kg}$ were used as Enset corm and Sugarcane. A completely randomized design was used and 4 bulls were allotted to a treatment. The result showed that bulls supplemented with Taro treatment had significantly $(P<0.05)$ higher daily intake of a total dry matter $(8.26 \mathrm{~kg} / \mathrm{bull})$ and nutrients while the daily intake of fresh grass $(5.33 \mathrm{~kg} / \mathrm{bull})$ on no supplemented treatment had significantly higher $(p<0.05)$. Bulls supplemented with Taro treatment had significantly $(P<0.05)$ higher average daily weight gain $(0.75 \mathrm{~kg} / \mathrm{bull})$ and lower feed to gain ratio (11.14). The extent of lean and fat meat per unit of animal implies that the amounts of total value added inform of raw meat in hotels and restaurants exceed 20,080 Birr. This also indicates that the specific value chain actors added more than $100 \%$ value for the live cattle that marketed 9500 Birr in the district. The highest and lowest net return was obtained from bulls fed Taro based supplement and sugarcane based supplement, respectively. It was concluded that fattening bulls by using Taro as energy supplement is recommended for the areas where Taro is available and cheap. Market actors that sell raw meat overexploit profit margin belong to producers that need systematic government intervention for efficient benefit share. Introduction Borana beef cattle with appropriate feeding intervention is believed to optimize the economics gains of actors in beef value chain.
\end{abstract}

Keywords: Boloso 1 taro; Fattening; Energy supplement; Oxen

\section{Introduction}

Ethiopia has the largest livestock population in Africa with an estimated of 56.71 million heads of cattle, 29.33 sheep, 29.11 goat and 1.16 million and 56.87 million poultry of meat producing animals. Despite this huge potential of livestock population and its diversity, the benefits obtained from the sector are low compared to other African countries and the world standard. As cited in Negassa et al. [1-3] our country average beef yield per animal of $108.4 \mathrm{~kg}$ is by far less than 119 $\mathrm{kg}$ for the Sudan, $146 \mathrm{~kg}$ for Kenya, $127 \mathrm{~kg}$ for eastern Africa, $146 \mathrm{~kg}$ for Africa, and $205 \mathrm{~kg}$ for the whole world.

To improve this scenario, various research activities have been undertaken in different parts of the country. The recent study on evaluation of feedlot performance of Wolaiyta area on zebu breed using locally available feeds (Taro, enset corm, sugercane and local grasses) at similar ages at Areka Agricultural Research Center indicated that the locally available feeds have a good potential to substitute factory by products for fattening. Looking for different feeding and management options for zebu breed in southern Ethiopia fattening experiment was done using locally available forage crops in the region. The results of feeding experiment indicates that the root crops especially taro and Enset corm could potentially substitute factory by products and yield organic beef that known as the cultural food in the district with special tests and consumption behaviors.

The endeavors so far made regarding beef cattle research were either fragmented or less targeted the actual domestic and international market. Conscious of this fact, this beef cattle fattening using locally available feeds is prepared to generate feasible technologies to meet the required international as well as local market weight for beef cattle of different ages for different breeds at different agro-ecologies.
The productivity of taro was recorded at Areka as $39.00 \mathrm{t} / \mathrm{ha}$. The most important feature of taro is its good adaptability, resistant to different diseases and Produce high amount of yields in different areas. Laboratory analysis of Boloso 1 taro for functional properties such as solubility, bulk density and water absorption index showed $24.17 \%$, $0.81 \mathrm{~g} / \mathrm{ml}$ and $1 \mathrm{ml} / \mathrm{g}$ respectively (Dagne [4]).

Creating advanced awareness on family planning practices in the rural areas, empowering females' participation in beef value chain, encouraging savings of income obtained from other sources, linking producers to market, practicing adult education policy in the rural areas, improving credit delivery system and also accessing it, providing trainings on improved beef cattle fattening practices, adoption of improved value development, beef value chain governance and value addition activities as an intervention (Halala et al. [5,6]).

Among different problems of animal production, shortage of feed quantity and quality are the most limiting factors. Livestock feed resources in Ethiopia are mainly natural grazing and browse, crop residues, improved pasture, forage crops and agro-industrial byproducts. At present, stock are fed almost entirely on natural pasture

*Corresponding author: Zekarias Bassa, Southern Agricultural Research Institute, Areka Agricultural Research Center, Areka, Ethiopia, Tel: +251913918474/+251465521125; Fax: +251465520502; E-mail: bassazekarias@yahoo.com

Received July 26, 2016; Accepted August 11, 2016; Published August 18, 2016

Citation: Bassa Z, Wolde S, Alemu T, Yilma M, Terra A, et al. (2016) Evaluation of Locally Available Energy Source Feeds on Fattening Performance of Local Oxen and Carcass Analysis in Wolaita, Southern Ethiopia. Hydrol Current Res 7: 255 doi: 10.4172/2157-7587.1000255

Copyright: ( 2016 Bassa Z, et al. This is an open-access article distributed under the terms of the Creative Commons Attribution License, which permits unrestricted use, distribution, and reproduction in any medium, provided the original author and source are credited. 
and crop residues. Grazing is on permanent grazing areas, fallow land and cropland after harvest (Mengistu [7]).

Crop-livestock mixed farming system is one of the predominant farming systems in the rural community of the central southern region of Ethiopia. Shortage of land due to population pressure is pushing many more farmers either to intensify the cropping system and or diversify the system using other integrated activities. Cattle fattening is among an integral componential activities (Getahun [8]).

Meat from ruminants forms the major source of animal protein in the country. The efficient management of ruminants in the tropics must first rely on the type and quality of forage available and the supplementation required to provide adequate diet (Jokthan et al. [9]). Beef producers rely heavily on forages as the basis of feeding programmers, forages must of necessity be supplemented with energy and or protein if fast growth rates are to be achieved (Vecchiettini [10]).

However, the availability of conventional energy source feeds is limited and costly than that of non-conventional ones. According to survey result, farmers supplement different root crops and sugar cane for intensive fattening of local oxen in central southern region of Ethiopia (Wolde et al. [11]). Currently data is scanty in feeding locally available energy source feeds such as Taro, Enset tuber and sugarcane for the fattening performance of local oxen.

\section{Objectives}

- To determine the effect of feeding different energy source feeds on feed intake and weight gain of fattening local oxen

- To undertake carcass analysis of experimental oxen

- To identify most efficient and cost effective feed

\section{Materials and Methods}

\section{Study site}

The experiment was conducted at Areka Agricultural Research Center, Mante Dubo sub-research site. The site is located at a distance of about $309 \mathrm{~km}$ south of the capital, Addis Ababa and at an altitude of

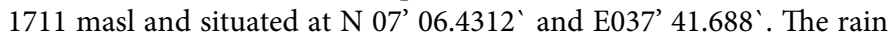
fall is bimodal and ranges between 1201 and $1600 \mathrm{~mm}$ with highest from July to September. The mean annual temperature ranges between $22^{\circ} \mathrm{C}$ and $24^{\circ} \mathrm{C}$.

\section{Management of experimental animals}

A total of 16 local un-castrated oxen of about 5 year's age were purchased from a local market of Areka. They were identified by using ear tags. Animals were de-wormed for internal parasite. After 14 days of adaptation period, they were categorized ( 4 block) on weight basis and 4 animals were randomly distributed to each treatment ( 1 from each block) and then each animal was randomly assigned to each replicate by using randomized complete block design. Each animal was treated as a replicate of concentrates, which was purchased from Licha union at Hosana.

Each animal was offered $2 \mathrm{~kg}$ of concentrate daily after offering green grass in the morning (10:00 am). The experimental diet (Taro, Enset and sugar cane) were offered on DM basis in the afternoon (2:00 $\mathrm{pm}$ ) at the level of $0.5 \%$ of body weight by considering $2.5 \%$ of body weight DM was fulfilled from green grass and concentrate from the total $3 \%$ body weight required for fattening oxen. Basal feed (fresh grass) was available on adlib bases. The daily offer of fresh grass was $25 \%$ more than the previous day intake. The weight of an animal at the end of a second week was used to calculate the weight of feed supplement that was offered to that particular animal the following two week.

Experimental diet (including basal feed) offered and refusals was weighed and recorded daily. The animals were individually housed in pens and data was collect for 98 days during which time the animals were weighed at the beginning, fortnightly during the trial and at the end of experimental period. Animals were weighed using heartgirth measurement $(\mathrm{cm})$ and then converted to $\mathrm{kg}$ basis by using the equation $(y=4.21 \mathrm{x}-365$, where $\mathrm{y}$ is weight of oxen in $\mathrm{kg}$ and $\mathrm{x}$ is heart girth in $\mathrm{cm}$ ) derived for Abyssinian short-horned zebu oxen in the Ethiopian highlands (Goe et al. [12]).

Caracas analysis was done in international elfora in Debrezait. The caracass analysis was done using 8 bulls in total and 2 animals per feed treatment were selected randomly.

\section{Experimental feeds}

Fresh grass was used as a basal diet. Concentrate, Taro (Bolosso-1), Enset corm and sugar cane stem were used as a feed supplement. Grass was cut and offered on green form. Concentrate was slightly mixed with water before offering to facilitate consumption. Taro and Enset corm were washed, chopped and wilted for about 4 hours before offering them to the oxen. Representative feed samples were taken every week during the trial and finally bulked and taken for chemical analysis. The treatment feeds were the following:

$$
\begin{aligned}
& \mathrm{T} 1=\text { fresh grass (adlib) }+2 \mathrm{~kg} \text { concentrate (control) } \\
& \mathrm{T} 2=\text { fresh grass (adlib) }+2 \mathrm{~kg} \text { concentrate+Taro (weight basis) } \\
& \mathrm{T} 3=\text { fresh grass (adlib) }+2 \mathrm{~kg} \text { concentrate+Enset (weight basis) } \\
& \mathrm{T} 4=\text { fresh grass (adlib) }+2 \mathrm{~kg} \text { concentrate+Sugar cane (weight basis) }
\end{aligned}
$$

\section{Chemical analysis}

Feed samples were oven dried at $65^{\circ} \mathrm{C}$ for $72 \mathrm{~h}$ and analyzed for DM, $\mathrm{N}$ (Kjeldahl-N) according to AOAC procedures. Neutral Detergent Fiber (NDF) and Acid Detergent Fiber (ADF) were determines by the methods of Van Soest and Robertson. Himi cellulose was calculated from the difference between $\% \mathrm{NDF}$ and $\% \mathrm{ADF}$.

\section{Partial budget analysis}

Partial budget analysis of treatment diets was calculated by the formula: Net return=GR (sale price of oxen) - TVC (total cost of feed consumed).

\section{Data analysis}

Data collected were subjected to Analysis of variance using the General Linear Model procedure of SPSS version 16. Where F tests declared significance at $\mathrm{P}<0.05$, means were separated using Duncan multiple range test.

\section{Results and Discussion}

\section{Dry matter and nutrient intake}

As indicated in Table 2, the DM and nutrient intake of oxen fed T2 was significantly higher $(\mathrm{p}<0.05)$ than $\mathrm{T}, \mathrm{T} 3$ and $\mathrm{T} 4$, however oxen fed T1 was significantly lowest. Oxen fed T3 and T4 were significantly $(\mathrm{p}<0.05)$ higher than T1 in DM and nutrient intake.

The highest DMI of Bolosso-1 supplemented diet (T2) as compared to T3 and T4 diets might be due to better in palatability and quality (Jokthan et al. $[13,14]$ ) and very high proportion of the digestible 
organic matter digestibility (81.41\%) and lowest lignin content $(2.91 \%)$ that make easy digestion and the feed pass through the rumen very fast (http://beef.unl.edu). The fresh grass intake of oxen fed T1 was significantly highest $(\mathrm{p}<0.05)$, which might be attributed to oxen fed more grass at T1 to fulfill the daily DMI required for maintenance and production. Consistent with the present study, Jokthan [13] reported that hay intake of fattening oxen supplemented with wheat offal, maize offal, rice offal and sorghum offal was not significant $(p>0.05)$. Moreover, similar trend was reported by (Adebabay et al. [14]) who observed lowest daily hay intake $(4.02 \mathrm{~kg})$ of fattening oxen at highest level of concentrate ration feeding. The average daily DMI of fattening local oxen in Wolaita in the present study and Adet highland zebu (Adebabay et al. [14]) is $7.65 \mathrm{~kg}$. Inconsistent with the present study, the average daily DMI of Fogera oxen is higher $(8.70 \mathrm{~kg} /$ day) (Adebabay et al. [14]) which might be due to better body size and weight of Fogera breed.

\section{Weight gain and feed to gain ratio}

Initial and final heart girth, initial and final weight; total and average daily gain and dry matter conversion ratio of the experimental oxen are presented in Table 2. Average daily gain of oxen fed T2 diet were significantly higher $(\mathrm{p}<0.05)$ than other treatment diets. There was no significant $(\mathrm{p}>0.05)$ difference between oxen fed T3 and T4 diets, but oxen fed T1 diet were fall in between in weight gain (Table 3 ). The weight gain performance of oxen fed $\mathrm{T} 2$ diet was higher whereas oxen fed T4 and T1 was lower throughout experimental period (Figure 1). The DM conversion ratio of bulls fed $\mathrm{T} 3$ and $\mathrm{T} 4$ diet were significantly higher $(\mathrm{p}<0.05)$ than T2 but bulls fed T1 diet were fall in between.

The high DMI of bulls fed T2 diet results high nutrient intake and high gain. The daily weight gain of bulls fed Enset and sugarcane based diet was similar to value of $2 \mathrm{~kg}$ concentrate based diet $(0.53 \mathrm{~kg} /$ day), but lower than $4 \mathrm{~kg}$ concentrate based diet $(0.93 \mathrm{~kg} /$ day $)$ and $6 \mathrm{~kg}$ concentrate based diet (0.53 kg/day) (Adebabay et al. [14]). The weight gain of bulls fed Taro based diet was comparable to value of $0.7 \mathrm{~kg} /$ day reported by Aduku [15]. Except Taro based diet, all other gains were lower than values obtained in other fattening trials conducted in
Nigeria (0.69-0.91 kg/day) (Lamidi et al. [16]). The average daily gain of bulls in welayta was comparable with values of $0.65 \mathrm{~kg} /$ day for Adet old oxen but lower than the values of $0.913 \mathrm{~kg} /$ day for Fogera old oxen in Amhara region of Ethiopia (Adebabay et al. [14]).

Oxen fed T2 diet required lowest amount of dry matter to gain similar weight indicating that better digestibility of Taro supplement (Table 1). The average value of DM conversion ratio of bulls obtained in the present study (13.93) was lower than values (17.42) obtained in other fattening trials conducted in Nigeria (Jokthan [9]) might be due to that the feeds in the present study were better in quality (Hersom [17]).

As indicated in Table 4, supplementing different locally available energy source feeds on fattening ration of local oxen in Wolaita moderately affects net return. The highest and lowest net return was obtained from bulls fed Taro based supplement and sugarcane based supplement, respectively. For small scale farmer that indulged with capital shortage and possess better access and use of locally available feeds (taro and enset corm), promoting cattle fattening using the defined feed technology believed to play significant role in optimizing economic benefits for small scale farmers, could creates a great job opportunity for youths, women and willing investors that could be involved in the sector and increase productivity of the sector.

\section{Results and discussion of carcass analysis}

The average live weight of experimental bull was $281.25 \mathrm{~kg}$ and the study result justified that animals that used different energy supplement have different weight gain. The study results also indicates that the dressing percentage (60.7\%) for zebu beef cattle in Wolaita area which is not in line with Pavanello [3] that states the country level dressing percentage $50 \%$. The research result also showed is the beef meat of Ethiopia amount of lean and fat meat per unit of cattle is more than 125 $\mathrm{kg}$ that not agrees the study result of Pavanello [3] where the meat yield was stated to be $108.4 \mathrm{~kg}$ per cattle in the country level (Tables 5-7).

The research result indicates that Taro could potentially substitute factory by products and animals consumed these locally available feeds can reach to market within three months of fattening period. The other

\begin{tabular}{|c|c|c|c|c|c|c|c|c|c|}
\hline Feeds & DM\% & Ash\% & ОМ\% & NDF\% & ADF \% & ADL\% & $\mathrm{CP} \%$ & DOMD\% & $\begin{array}{c}\text { Energy (MJ/ } \\
\text { kg DM) }\end{array}$ \\
\hline Natural pasture & 95.145 & 9.722 & 90.28 & 74.92 & 46.99 & 8.47 & 6.243 & 51.77 & 8.28 \\
\hline Enset amicho & 90.05 & 4.464 & 95.54 & 32.48 & 10.74 & 4.36 & 4.214 & 71.67 & 11.47 \\
\hline Bolosso - 1(Taro) & 89.41 & 4.021 & 95.98 & 69.31 & 6.84 & 2.91 & 4.162 & 81.41 & 13.02 \\
\hline Sugar cane stem & 93.395 & 3.887 & 96.11 & 45.67 & 29.8 & 7.0 & 3.422 & 59.56 & 9.53 \\
\hline Concentrate & 91.52 & 7.004 & 93.00 & 38.20 & 9.1 & 3.7 & 14.798 & 69.14 & 11.06 \\
\hline
\end{tabular}

Table 1: Chemical Composition and Digestible Organic Matter Digestibility of feeds.

\begin{tabular}{|c|c|c|c|c|c|c|}
\hline Parameters & T1 & T2 & T3 & T4 & Overall mean & SEM \\
\hline DMI, Grass & $5.33^{b}$ & $4.63^{a}$ & $4.59^{\mathrm{a}}$ & $4.46^{\mathrm{a}}$ & 4.76 & 0.05 \\
\hline DMI, Concentrate & 1.78 & 1.78 & 1.78 & 1.78 & 1.78 & 0 \\
\hline DMI, Taro & - & 1.84 & - & - & 1.84 & 0 \\
\hline DMI, Enset corm & - & - & 1.17 & - & 1.17 & 0 \\
\hline DMI, Sugarcane & - & - & - & 1.45 & 1.45 & 0 \\
\hline Total DMI & $7.11^{\mathrm{a}}$ & $8.26^{c}$ & $7.55^{b}$ & $7.69^{b}$ & 7.65 & 0.06 \\
\hline Ash intake & $0.57^{a}$ & $0.66^{c}$ & $0.60^{b}$ & $0.61^{\mathrm{b}}$ & 0.61 & 0.01 \\
\hline Organic matter intake & $6.47^{a}$ & $7.51^{\mathrm{c}}$ & $6.99^{b}$ & $6.87^{b}$ & 6.96 & 0.05 \\
\hline NDF intake & $4.05^{a}$ & $4.71^{\mathrm{c}}$ & $4.30^{b}$ & $4.38^{b}$ & 4.36 & 0.03 \\
\hline ADF intake & $1.99^{a}$ & $2.31^{c}$ & $2.11^{b}$ & $2.16^{b}$ & 2.14 & 0.02 \\
\hline ADL intake & $0.43^{a}$ & $0.50^{\circ}$ & $0.45^{b}$ & $0.46^{b}$ & 0.46 & 0.004 \\
\hline $\mathrm{CP}$ intake & $0.57^{a}$ & $0.66^{c}$ & $0.60^{b}$ & $0.62^{b}$ & 0.61 & 0.01 \\
\hline Energy intake & $0.68^{a}$ & $0.79^{c}$ & $0.73^{b}$ & $0.74^{b}$ & 0.73 & 0.01 \\
\hline
\end{tabular}

Table 2: Dry matter intake (DMI) (kg/ox/day), nutrient intake (kg/ox/day) and energy intake (MJ/ox/day) of experimental oxen. 


\begin{tabular}{|c|c|c|c|c|c|c|}
\hline & \multicolumn{2}{|c|}{ Treatment diets } & T4 & Overall mean \\
\hline Parameters & T1 & T2 & T3 & SEM \\
\hline Initial heart girth, cm/ox & 142.50 & 146.25 & 148.00 & 146.75 & 145.88 & 0.99 \\
\hline Final heart girth, cm/ox & 156.25 & 163.75 & 159.50 & 158.25 & 159.44 & 1.24 \\
\hline Initial weight, kg/ox & 234.93 & 250.71 & 258.08 & 252.82 & 249.13 & 4.15 \\
\hline Final weight, kg/ox & 292.81 & 324.39 & 306.50 & 301.23 & 306.23 & 5.22 \\
\hline Total weight gain, kg/ox & $57.89^{\mathrm{ab}}$ & $73.68^{\mathrm{b}}$ & $48.42^{\mathrm{a}}$ & $48.42^{\mathrm{a}}$ & 57.10 & 3.12 \\
\hline Average daily gain, kg/ox & $0.59^{\mathrm{ab}}$ & $0.75^{\mathrm{b}}$ & $0.49^{\mathrm{a}}$ & $0.49^{\mathrm{a}}$ & 0.58 & 0.03 \\
\hline Dry matter conversion ratio (DMl/weight gain) & $12.85^{\mathrm{ab}}$ & $11.14^{\mathrm{a}}$ & $15.83^{\mathrm{b}}$ & $15.89^{\mathrm{b}}$ & 13.93 & 0.71 \\
\hline
\end{tabular}

Table 3: Body weight gain and dry matter conversion ratio of experimental oxen.

\begin{tabular}{|c|c|c|c|c|}
\hline Parameters & T1 & T2 & T3 & T4 \\
\hline Total DM consumed, kg/ox & 697.11 & 809.25 & 739.59 & 753.79 \\
\hline Cost of feed, ETB/kg DM & 2.66 & 2.95 & 4.41 & 3.67 \\
\hline Total cost of feed consumed, ETB (TVC) & 1854.31 & 2389.47 & 3257.83 & 2768.07 \\
\hline Purchase of ox, ETB/head & 5925 & 5850 & 6225 & 6225 \\
\hline Sale of ox, ETB/head & 9531.25 & 10918.75 & 10671.88 & 9187.5 \\
\hline Gross profit (GR), ETB/head & 3606.25 & 5068.75 & 4446.88 & 2962.5 \\
\hline Net return (GR-TVC), ETB/head & 1751.94 & 2679.28 & 1189.05 & 194.43 \\
\hline Average Lean and fat meat & 130.00 & 137 & 134 & 114.50 \\
\hline Price of beef meat per kg (Birr) & 160 & 160 & 160 & 160 \\
\hline Value of beef cattle inform of raw Meat) & 20800 & 22080 & 21440 & 18320 \\
\hline net Value added & 11268.75 & 11161.25 & 10768.1 & 9133 \\
\hline
\end{tabular}

Table 4: Partial budget analysis of treatment diets.

\begin{tabular}{|c|c|c|c|c|c|c|c|c|c|c|c|c|c|c|}
\hline $\begin{array}{l}\text { Caracas traits } \\
\text { in kg and } \\
\text { statistical } \\
\text { parameters }\end{array}$ & Head & Feet & Tongue & Skin & $\begin{array}{l}\text { Testis and } \\
\text { penis }\end{array}$ & Lung & Heart & $\begin{array}{l}\text { Spleen and } \\
\text { pancreas }\end{array}$ & $\begin{array}{l}\text { Kidney } \\
\text { with fat }\end{array}$ & Liver & $\underset{\text { fat }}{\text { Omental }}$ & gut full & $\begin{array}{c}\text { gut } \\
\text { empty }\end{array}$ & $\begin{array}{l}\text { intestine } \\
\text { full }\end{array}$ \\
\hline Mean & 13.70 & 4.50 & 1.46 & 18.63 & 1.34 & 3.14 & 0.94 & 0.98 & 2.51 & 3.79 & 5.03 & 30.69 & 9.21 & 13.31 \\
\hline Std. Dev. & 1.13 & 0.44 & 0.23 & 2.55 & 0.21 & 0.57 & 0.07 & 0.29 & 0.62 & 0.32 & 1.44 & 2.71 & 0.74 & 3.06 \\
\hline Minimum & 11.73 & 3.71 & 0.98 & 13.50 & 1.05 & 2.50 & 0.80 & 0.68 & 1.95 & 3.09 & 3.27 & 26.00 & 8.53 & 10.00 \\
\hline Maximum & 15.50 & 4.99 & 1.74 & 21.00 & 1.67 & 4.43 & 1.02 & 1.64 & 3.80 & 4.11 & 7.70 & 34.50 & 10.80 & 17.00 \\
\hline
\end{tabular}

Table 5: Beef offal traits.

\begin{tabular}{|c|c|c|c|c|c|c|c|c|c|c|c|}
\hline Forequarter traits and & chuckroll & Sholderclod & ribeye ball & Biceps & Hump & Brisket & plate & Forshank & Forebone & forefat & forelean \\
\hline Mean & 26.4 & 14.19 & 11.39 & 5.63 & 7.69 & 5.74 & 8.69 & 6.24 & 13.13 & 16.88 & 53.75 \\
\hline Std. Dev. & 3.37 & 1.87 & 1.68 & 1.14 & 1.60 & 1.28 & 1.49 & 1.16 & 1.96 & 5.06 & 7.05 \\
\hline Minimum & 21.5 & 12.2 & 10 & 5 & 6 & 4 & 6 & 4 & 10 & 12 & 44 \\
\hline Maximum & 32.5 & 17.24 & 14.5 & 8 & 11 & 8 & 10.78 & 7.5 & 16 & 24 & 68 \\
\hline Sum & 211.2 & 113.48 & 91.08 & 45 & 61.5 & 45.9 & 69.58 & 49.9 & 105 & 135 & 430 \\
\hline
\end{tabular}

Table 6: Forequarter caracass traits and statistics.

\begin{tabular}{|c|c|c|c|c|c|c|c|c|c|c|c|c|c|c|c|c|}
\hline $\begin{array}{l}\text { Caracas traits } \\
\text { in kg and } \\
\text { statistical }\end{array}$ & $\begin{array}{l}\text { Silver } \\
\text { Side }\end{array}$ & Nuckle & $\begin{array}{c}\text { Top } \\
\text { sirloin }\end{array}$ & Sirp loin & $\begin{array}{c}\text { Tender } \\
\text { Ioin }\end{array}$ & Trip tip & Ball tip & Flap & $\begin{array}{l}\text { Flank } \\
\text { steak }\end{array}$ & $\begin{array}{l}\text { False } \\
\text { lean }\end{array}$ & $\begin{array}{l}\text { Soft } \\
\text { shin }\end{array}$ & $\begin{array}{l}\text { Hard } \\
\text { shin }\end{array}$ & Topside & $\begin{array}{l}\text { Hind } \\
\text { Bone }\end{array}$ & $\begin{array}{l}\text { Hind } \\
\text { Lean } \\
\text { meat }\end{array}$ & $\begin{array}{c}\text { Hind } \\
\text { Fat } \\
\text { meat }\end{array}$ \\
\hline Mean & 10.41 & 4.65 & 7.40 & 6.08 & 3.02 & 2.18 & 2.18 & 6.64 & 1.98 & 1.35 & 2.29 & 2.54 & 9.20 & 10.13 & 44.75 & 13.75 \\
\hline Std. Dev. & 1.35 & 0.35 & 1.96 & 0.58 & 0.64 & 0.66 & 0.66 & 1.16 & 0.50 & 0.52 & 0.53 & 0.33 & 0.54 & 2.03 & 4.80 & 4.30 \\
\hline Minimum & 9.00 & 4.00 & 4.00 & 5.00 & 2.00 & 1.50 & 1.50 & 5.00 & 1.30 & 1.00 & 1.50 & 2.00 & 8.5 & 8 & 37 & 7 \\
\hline Maximum & 12.50 & 5.00 & 11.00 & 6.62 & 4.00 & 3.50 & 3.50 & 9.00 & 3.00 & 2.50 & 3.00 & 3.00 & 10 & 14 & 52 & 20 \\
\hline Sum & 83.26 & 37.20 & 59.16 & 48.62 & 24.12 & 17.40 & 17.40 & 53.12 & 15.84 & 10.82 & 18.32 & 20.30 & 73.62 & 81 & 358 & 110 \\
\hline
\end{tabular}

Table 7: Statistics of Hindquarter carcass traits.

experimental animals that consumed, Enset corm, sugarcane tops and control group could not be reached to the body condition that needs additional fattening periods and it could impose to additional costs. For experimental animals that used taro, daily intake feeds and subsequent addition of respective weight gain showed decreasing trends. The daily intake of feeds of and subsequent changes in weight for animals used sugarcane and non-energy supplements showed increasing trends. This show that three months period of fattening for animal used taro is adequate to attain market weight.

\section{Conclusion}

The overall results of the present study revealed that oxen fed Taro as energy supplement were performed better than oxen fed other feed supplements. Moreover the net return of oxen fed Taro based supplement was highest. The study confirmed that fattening oxen by using Taro as energy supplement is recommended for areas where Taro is available and cheap. In addition to these, fattening using locally available and productive taro variety helps to minimize fattening and 


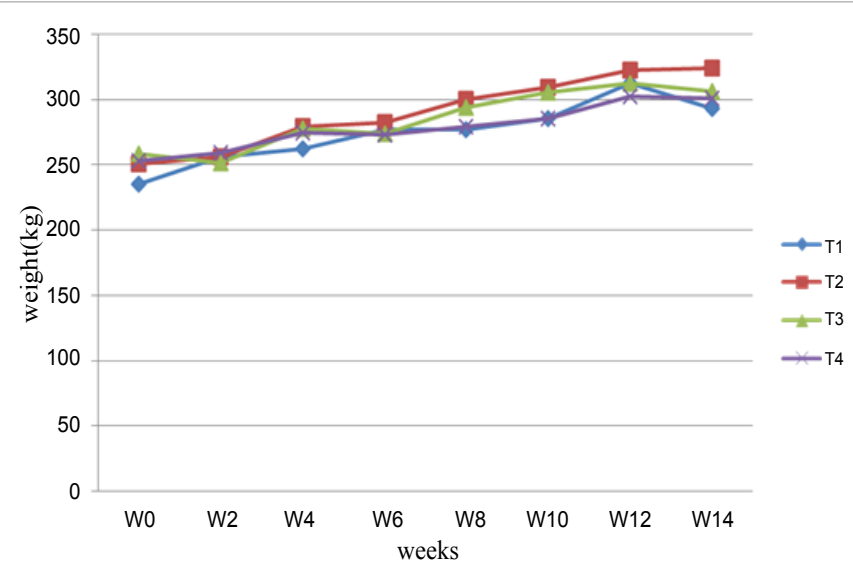

Figure 1: Weight gain of experimental bulls alloted to different feeds.

transaction costs, there by optimize economic gains of producers. It is therefore advisable to promote cattle fattening using Boloso 1 taro and the Organic beef obtained from the specific supplement. Adoption of beef cattle production and meat value chain analysis and development, organizing farmers in cooperatives, awareness creation and linking producers to market, pre-scaling the feed technology, promoting locally available and environmental adaptive feed is believed to help a lot in optimizing the sector and help to attain sustainable development. More over these, introduction of productive Boran breed to the district, giving due consideration for nutritious and adaptive locally feed supplement is believed to play a lot in increasing production and productivity of the sector.

\section{Recommendations}

* Undertaking taro based demonstration and pre-scaling of the feeding options

- Undertaking value chain analysis for beef cattle production

* Capacity building of subject matter specialists in implementing

* Organizing farmers, women and youths

* Demonstration and announcement of the endowment of organic meat in the region that could potentially compete meat industry in the world.

\section{Acknowledgements}

We would like to acknowledge Ethiopian Institute of Agricultural Research (EIAR) and Southern Agricultural Research Institute (SARI) for covering the study costs. Technical assistants; Ato Tewodros Getachew for active participation during bull purchase and ear tagging, Ato Temesgen Mena for follow up of the experiment during data collection and all data collectors at Mante research station. Holeta and Areka Agricultural Research Centers are highly appreciated for chemical analysis and material support, respectively.

\section{References}

1. Negassa A, Shahidur R, Gebremedhin B (2011) Livestock Production and Marketing in Ethiopia. Ethiopia Strategy Support Program II, ESSP II Working Paper, pp: 26-35.
2. Gebremedhin B, Hoekstra D, Jemaneh S (2007) Heading towards commercialization? The case of live animal marketing in Ethiopia. Improving Productivity and Market Success (IPMS) of Ethiopian Farmers Project Working Paper 5. ILRI (International Livestock Research Institute), Nairobi, Kenya, p: 73.

3. Pavanello $S$ (2011) Harnessing the potential of cross-border activities to improve livelihood Security in the Horn of Africa dry lands. HPG Policy Brief 41, Humanitarian Policy Group July 2010 working across borders, p: 32.

4. Dagne Y, Mulualem T, Kifle A (2014) Development of High Yielding Taro (Colocacia esculenta L.) Variety for Mid Altitude Growing Areas of Southern Ethiopia. Journal of Plant Sciences 2: 50-54.

5. Halala H (2015) Value chain analysis of Beef: The case of Sodo Zuriya and Offa District in Wolaita zone, Southern Nations Nationality people Region, Ethiopia. MSc Thesis, Jimma University, Jimma, Ethiopia, p: 124.

6. Bassa Z, Woldeamanuel T (2015) Value chain analysis of the cattle trade in Moyale, southern Ethiopia. An economic assessment in Oromiya Regional State. IIED Country Report. IIED, London.

7. Mengistu A (2003) Country Pasture/Forage Resource Profiles.

8. Getahun L (2008) Productive and economic performance of Small Ruminant production in production system of the Highlands of Ethiopia. PhD Dissertation. University of Hohenheim, Stuttgart-Hoheinheim, Germany, p: 21.

9. Jokthan GE (2003) Effect of different energy sources on intake and weight gain of white Fullani cattle. National Open University, Logos, Nigeria.

10. Vecchiettini M, Giardini A (2000) Cattle fattening: the Italian example. CIHEAMoptions mediterraneennes.

11. Wolde S, Bassa Z, Alemu T (2014) Assessment of cattle fattening and marketing system and constraints affecting cattle fattening in central southern region of Ethiopia. SPSS (Statistical Procedures for Social Sciences) 2001 SPSS BI Survey Tips. Statistical Procedures for Social Sciences (SPSS) Inc. Chicago, USA.

12. Goe MR, Alldredge JR, Light D (2001) Use of heart girth to predict body weight of working oxen in the Ethiopian highlands. Livestock Production Science 69: 187-195.

13. Jokthan GE, Lakpini CAM, Adamu AM, Akpa GN (2009) Effect of supplementing rice straw with pigion pea forage on performance of Yankasa sheep. Nig. J. of animal production 36: 134-142.

14. Adebabay K, Addisu B, Tewodros B, Asresu Y, Yihalem D, et al. (2013) Comparative evaluation of the fattening performance of Fogera and Adet old oxen at Andasa Livestock Research Center, Ethiopia. Int. Journal of Pharmamedicine and Biological Sciences 2: 66-75.

15. Aduku AO (2005) Tropical feedstuff analysis Table. Department of Animal Science, Faculty of Agriculture, Ahmadu Bello University, Zaria.

16. Lamidi OS, Adamu AM, Ehoche OW, Alawa JP (2007) Replacement value of sundried broiler litter for cotton seed cake in the fattening diets for Bunaji bulls. J. Anim. Prod. Res 20: 99-112.

17. Hersom M (2007) Basic nutrient requirements of beef cows. Department of Animal Science Series, University of Florida, Florida cooperative extension service, Institute of Food and Agricultural Science, Florida, USA. 